\title{
Dish Concentrator Performance Based on Various Materials for Hot Humid Weather
}

\author{
(Prestasi Penumpu Dish Berdasarkan Pelbagai Bahan untuk Cuaca Panas Lembap)
}

M. A. Mat Nong*, N. M. Adam, A. R. Suraya, J. M. Yusof and R. A. Rashid

\begin{abstract}
In this paper, three solar dish systems with different reflector materials were experimentally studied for five months. The size each of the solar dish is $32 \mathrm{~cm}$ in diameter and $5 \mathrm{~cm}$ in depth. The focal length of the dish concentrator was $12.8 \mathrm{~cm}$. The solar dishes were made from aluminum, aluminum covered with chrome and ABS canister covered with 3M aluminum foil on its surface. Experimental measurement for total heat flux showed that $3 M$ aluminum foil is higher than aluminum and chrome. The experimental results indicate that the total efficiency of the system is up to $49.7 \%$.
\end{abstract}

Keywords: solar dish, reflector, solar energy, focal point

ABSTRAK

Dalam kertas kerja ini tiga sistem solar dish dengan bahan-bahan pemantul berbeza telah diujikaji selama lima bulan. Solar dish ini mempunyai $32 \mathrm{~cm}$ garis pusat dan $5 \mathrm{~cm}$ dalam. Panjang fokus penumpu solar dish adalah $12.8 \mathrm{~cm}$. Solar dish ini diperbuat daripada aluminium, aluminium yang diselaputi krom pada permukaannya dan ABS canister yang ditutup dengan aluminium foil $3 M$ pada permukaannya. Pengukuran eksperimen untuk jumlah fluks haba menunjukkan aluminium foil $3 M$ adalah lebih tinggi daripada aluminium dan krom. Keputusan eksperimen menunjukkan bahawa jumlah kecekapan sistem boleh mencapai 49.7\%.

Kata kunci : solar dish, pemantul, tenaga solar, titik tumpuan

\section{INTRODUCTION}

Solar energy which originated from the conversion of heat from the sun has become an ideal solution for alternative and sustainable energy source. It is one of the cleanest energy resources that does not compromise or add to the global warming. It is also been called as "alternative energy" to fossil fuel energy sources such as oil and coal (Solangi et al. 2011). In line with the growing concerns about global warming and consequent climate change, renewable energy sources have become more attractive option for electricity generation around the world. Malaysia relies on fossil fuels, gas and coal which contribute to the global warming. As most of the natural resources, particularly that of fossil fuel depleting rapidly, more efficient ways to produce alternative energy for daily necessity is becoming important issues (Kamaruddin 2005).

An accurate data prediction on solar radiation in Malaysia is the most important part for solar energy application such as for photovoltaic and green building.
Being in tropical region, all ASEAN countries received very high daily solar radiation, averaging more than $4.5 \mathrm{kWh} / \mathrm{m}^{2}$. However, high solar radiation with large land area, points out that the solar resource is underutilized in the ASEAN region (Lidula et al. 2007).

The tropical environment has been characterized by heavy rainfall, constantly high temperature and relative humidity. The annual average daily solar irradiations for Malaysia were from $4.21 \mathrm{kWh} / \mathrm{m}^{2}$ to $5.56 \mathrm{kWh} / \mathrm{m}^{2}$. The highest solar irradiation is estimated at $6.84 \mathrm{kWh} /$ $\mathrm{m}^{2}$ in May while the lowest is $2.15 \mathrm{kWh} / \mathrm{m}^{2}$ in August as shown in Table 1. The Northern region and a few places in East Malaysia have the highest potential for solar energy application due to its high solar radiation throughout the year (Azahari et al. 2008). Meanwhile the average daily solar irradiation in Peninsular Malaysia using MD model is shown in Table 2. The highest average is $17.18 \mathrm{MJ}-\mathrm{m}^{-2}$ - day $^{6-1}$ in February and the low average is $13.67 \mathrm{MJ}-\mathrm{m}^{-2}$ - day $^{6-1}$ in November. 
TABLE 1. Solar irradiation data in Malaysia

\begin{tabular}{lccc}
\hline Month & $\begin{array}{c}\text { Solar irradiation } \\
\text { minimum } \\
\left(\mathrm{kWh} / \mathrm{m}^{2}\right)\end{array}$ & $\begin{array}{c}\text { Solar irradiation } \\
\text { maximum } \\
\left(\mathrm{kWh} / \mathrm{m}^{2}\right)\end{array}$ & $\begin{array}{c}\text { Solar irradiation } \\
\text { average } \\
\left(\mathrm{kWh} / \mathrm{m}^{2}\right)\end{array}$ \\
\hline January & 4.90 & 6.50 & 3.00 \\
February & 4.67 & 6.62 & 6.23 \\
March & 4.33 & 6.51 & 5.02 \\
April & 2.63 & 5.11 & 4.11 \\
May & 3.69 & 6.84 & 4.83 \\
June & 2.98 & 6.71 & 5.14 \\
July & 4.41 & 5.86 & 5.17 \\
August & 2.15 & 6.81 & 5.25 \\
September & 3.95 & 5.53 & 4.89 \\
October & 4.68 & 6.43 & 5.43 \\
November & 4.68 & 6.43 & 5.43 \\
December & 3.00 & 5.34 & 0.61 \\
\hline
\end{tabular}

WSEAS Transactions on Environment and Development: (Azhari A.W. et al. 2008)

This research focuses on solar dish concentrator as another alternative electricity source. Solar dish concentrator has advantages over concentrating collector due to the absence of cosine losses, high geometric concentration ratio and high temperature (Reddy et al. 2009). The important part during developing solar dish concentrator is identifying suitable and economical materials. Various materials like aluminum film and stainless steel was covered on the top of the different dimension dish concentrator. This material reacts as a solar reflector for the dish concentrator. It was found that aluminum is the best solutions for solar reflectance (Rafeeu \& Kadir 2012). Meanwhile (Hamza et al. 2016) found in their research stainless steel sheet is the appropriate reflectance selection because it is easy to assemble, clean and suitable for any type of weather conditions. Other related previous research used silver or glass mirror which has 91 and $95 \%$ solar reflectance range respectively (Bakos \& Antoniades 2013).

TABLE 2: Monthly average daily solar irradiation using MD model $\left(\mathrm{MJ} \cdot \mathrm{m}^{-2} \cdot \mathrm{day}^{6-1}\right)$

\begin{tabular}{|c|c|c|c|c|c|c|c|c|c|c|c|c|}
\hline City & Jan & Feb & Mar & Apr & May & Jun & Jul & Aug & Sep & Oct & Nov & Dec \\
\hline KLIA & 17.13 & 17.82 & 18 & 18.43 & 17.95 & 18.06 & 18.14 & 18.37 & 18.12 & 17.71 & 15.15 & 15.83 \\
\hline Muadzam Shah & 16.48 & 17.98 & 17.05 & 18.35 & 17.79 & 17.59 & 17.69 & 18.26 & 17.88 & 17.59 & 16.55 & 15.77 \\
\hline Ipoh & 16.39 & 17.62 & 17.01 & 17.58 & 17.59 & 17.95 & 18.76 & 16.73 & 18.14 & 16.72 & 15.3 & 15.96 \\
\hline Malacca & 14.29 & 15.93 & 16.8 & 18.06 & 16.38 & 17.53 & 16.54 & 15.83 & 16.54 & 16.82 & 13.73 & 14.13 \\
\hline Bayan Lepas & 16.91 & 17.27 & 16.73 & 16.8 & 15.5 & 17.72 & 17.81 & 14.41 & 15.45 & 15.06 & 14.35 & 15.32 \\
\hline Kuantan & 13.9 & 17.9 & 17.04 & 17.55 & 15.92 & 16.19 & 17.71 & 18 & 17.07 & 14.36 & 12.75 & 13.45 \\
\hline Senai & 17.16 & 17.17 & 17.6 & 18.03 & 16.61 & 17.2 & 15.11 & 16.06 & 15.02 & 16.07 & 12.36 & 14.48 \\
\hline Alor Setar & 15.98 & 17.83 & 16.17 & 14.15 & 17.42 & 17.77 & 15.99 & 13.93 & 15.7 & 16.09 & 11.91 & 15.54 \\
\hline Chuping & 19.28 & 18.34 & 16.69 & 17.09 & 16.63 & 18.3 & 16 & 15.24 & 16.23 & 15.53 & 13.97 & 18.25 \\
\hline Kota Bharu & 12.8 & 17.52 & 15.64 & 15.75 & 15.82 & 16.38 & 14.11 & 16.8 & 15.16 & 13.64 & 12.5 & 14.08 \\
\hline Kuala Terengganu & 11.16 & 17.26 & 14.89 & 14.66 & 12.04 & 14.07 & 11.89 & 14.15 & 12.5 & 12.35 & 10.53 & 11.24 \\
\hline $\operatorname{Max}$ & 19.28 & 18.34 & 18 & 18.43 & 17.95 & 18.3 & 18.14 & 18.37 & 18.14 & 17.71 & 16.55 & 18.25 \\
\hline Min & 11.16 & 14.8 & 14.89 & 14.15 & 12.04 & 14.07 & 11.89 & 13.93 & 12.5 & 12.35 & 10.53 & 11.24 \\
\hline Ave & 15.13 & 17.18 & 16.71 & 16.85 & 16.28 & 16.99 & 16.10 & 16.11 & 16.26 & 15.45 & 13.67 & 14.71 \\
\hline
\end{tabular}

Hindawi Publishing Corporation : (Aghil Shavalipour et al. 2013) 


\section{OBJECTIVE}

The objective of this project is to determine the heat flux reflectance given by various materials used in the solar dish concentrator to select the most effective material which can give maximum solar reflectance.

\section{METHODOLOGY}

Geometry of the solar dish concentrator was $1 / 100$ scaled down from the UPM solar bowl. The initial phase consists of three solar dishes which were made from different materials. These materials are aluminum, aluminum covered with chrome and ABS canister covered with $3 \mathrm{M}$ aluminum on the surface. The aluminum dish and aluminum chrome dish was made using $\mathrm{CNC}$ milling machine at Technology Park Malaysia. The third dish was made using rapid prototyping machine at Institute of Advanced Technology (ITMA), UPM. All dishes have same dimension and geometry parameter.

The dish concentrator system referring to Figure 2 has a coil tube made from chrome on the focal point. The water flows in and out at the coil tube. The heat flux from the reflector material was measured at the focal point

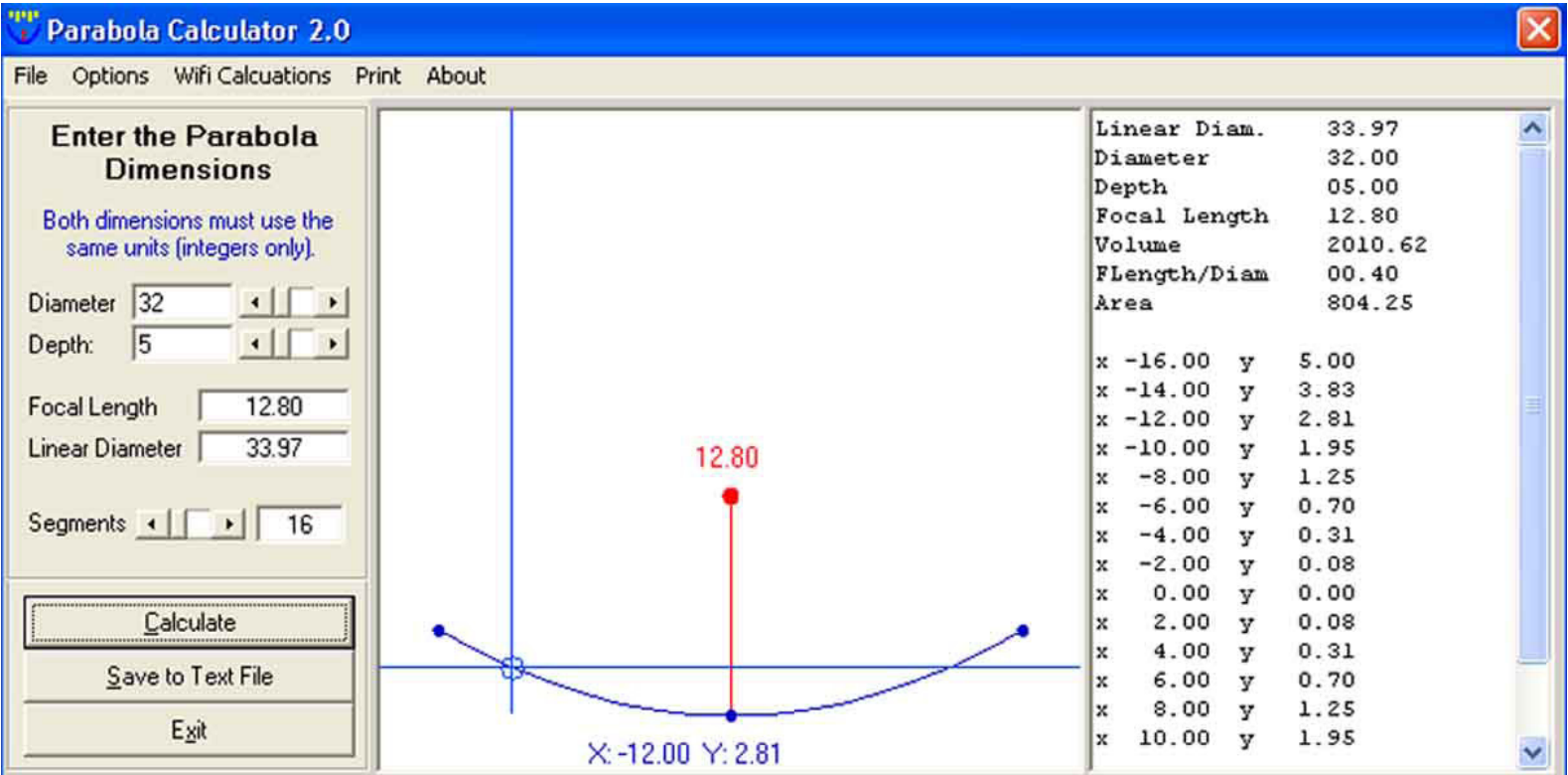

FIGURE 1. Solar dish dimension parameter using parabola calculator

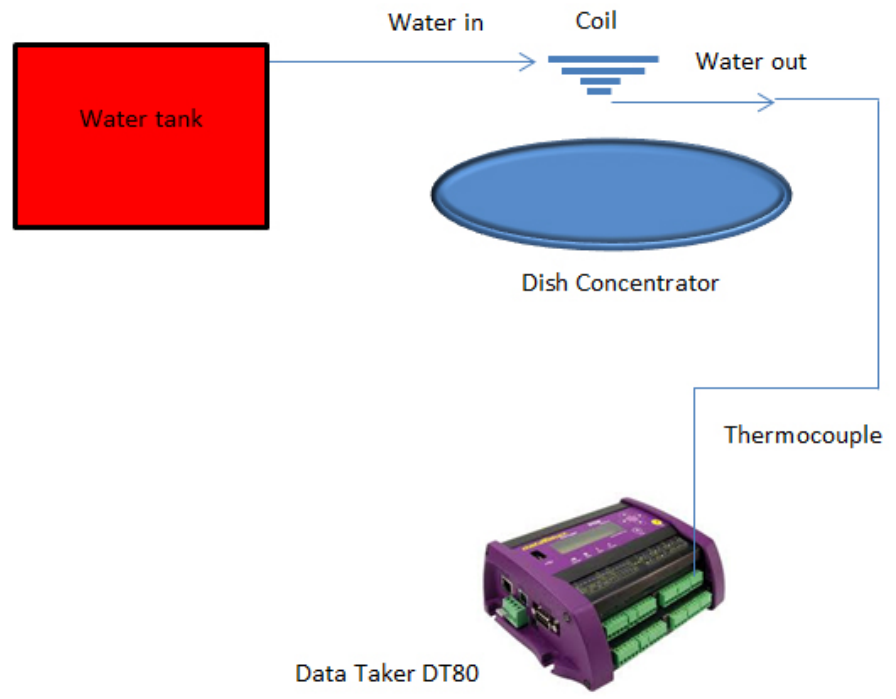

FIGURE 2. Experiment process 


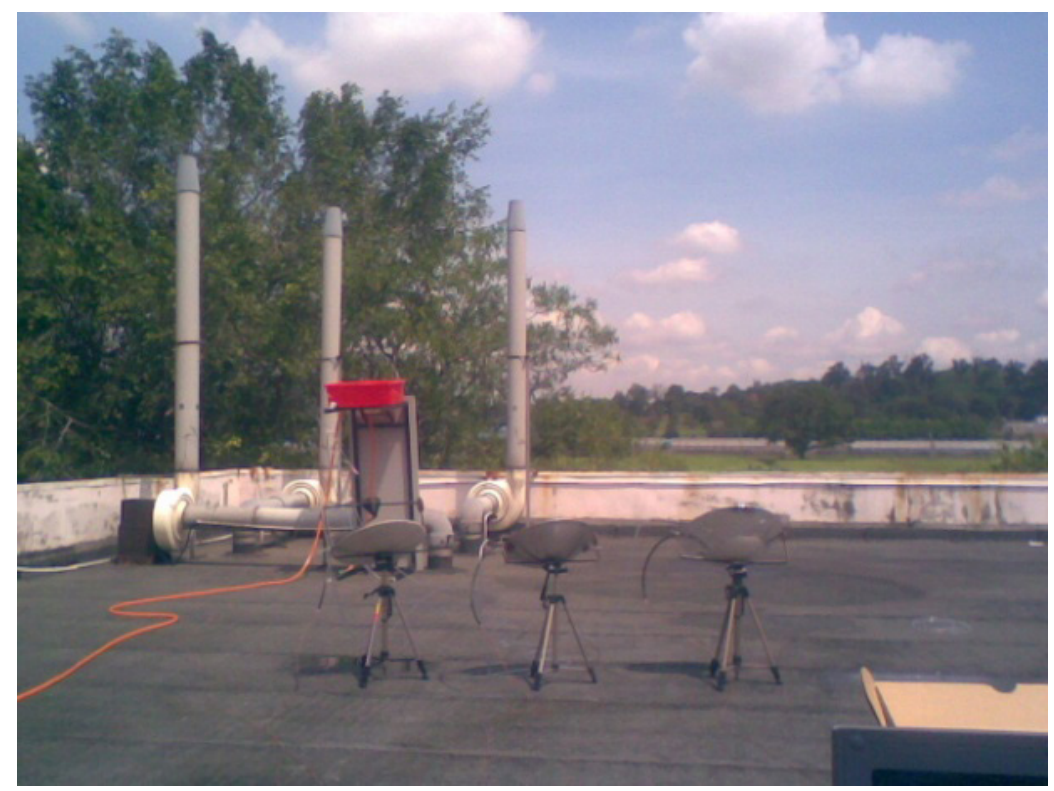

FIGURE 3. Solar dish concentrator setup systems in afternoon

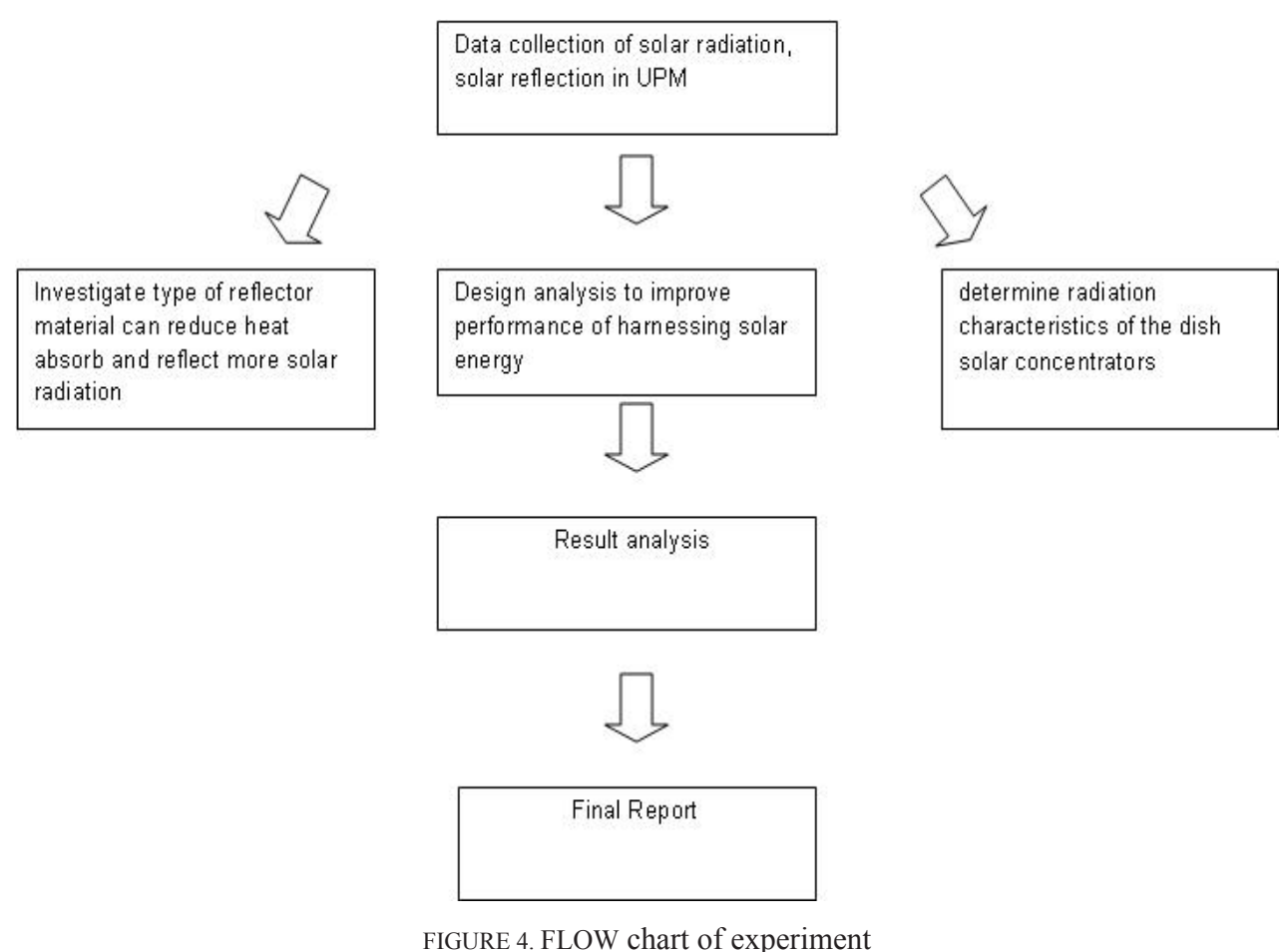

RESULTS AND DISSCUSSION

using k-type thermocouple connected with the data logger. The data was collected from 10 am until $4 \mathrm{pm}$ at the top of the ITMA Block D building roof as shown in Figure 3. The environment condition and solar irradiation were measured using TSI velocity meter and pyranometer. The data was collected for five months. The flow chart of the experiment process is given in Figure 4. The parameter was calculated using parabola calculator [http://mscir. tripod.com/parabola/] in Figure 1 before a prototype dish was made.
Figure 5-9 shows values of data collected for five months, March, April, May, June and July. This plotted graph shows that $3 \mathrm{M}$ aluminum foils reflected heat higher than aluminum and chrome throughout the 5 months observation period. The solar irradiation increased proportional to the temperature as recorded by Datataker DT80. It was observed that the minimum reflected heat collected was in the morning. The temperature increased until noon and dropped slowly in the evening. The temperatures also dropped during cloudy sky. The maximum and minimum temperatures collected were $50^{\circ} \mathrm{C}$ and $25^{\circ} \mathrm{C}$. 
There main problem faced during the experiment was thick cloud covering the rays of sunlight thus reflected to the temperature difference which recorded at $29^{\circ} \mathrm{C}$ but the actual temperature can be reach to $37^{\circ} \mathrm{C}$. Data collected from this study shall provide baseline information for current solar irradiation at Universiti Putra Malaysia.

Energy efficiency of solar dish concentrator can be defined as the ratio of energy output (only the increase of the water energy due to temperature growth) to the energy input (the energy of solar radiation) (Ozturk et al. 2004). A formulae efficiency of solar dish concentrator can be calculated as follows;

$$
\frac{\eta=m c(T w f-T w i)}{\frac{\Delta t}{I A}}
$$

$\eta \quad=$ efficiency

$\mathrm{m}=$ mass of water $(\mathrm{kg})$

$\mathrm{c} \quad=$ specific heat of water $(\mathrm{J} / \mathrm{kgK})$

$\mathrm{Twf}=$ water temperature final

Twi $=$ water temperature initial

$\Delta \mathrm{t}=$ time interval

$1=$ solar irradiation $\left(\mathrm{W} / \mathrm{m}^{2}\right)$

A $=$ area $\left(\mathrm{m}^{2}\right)$

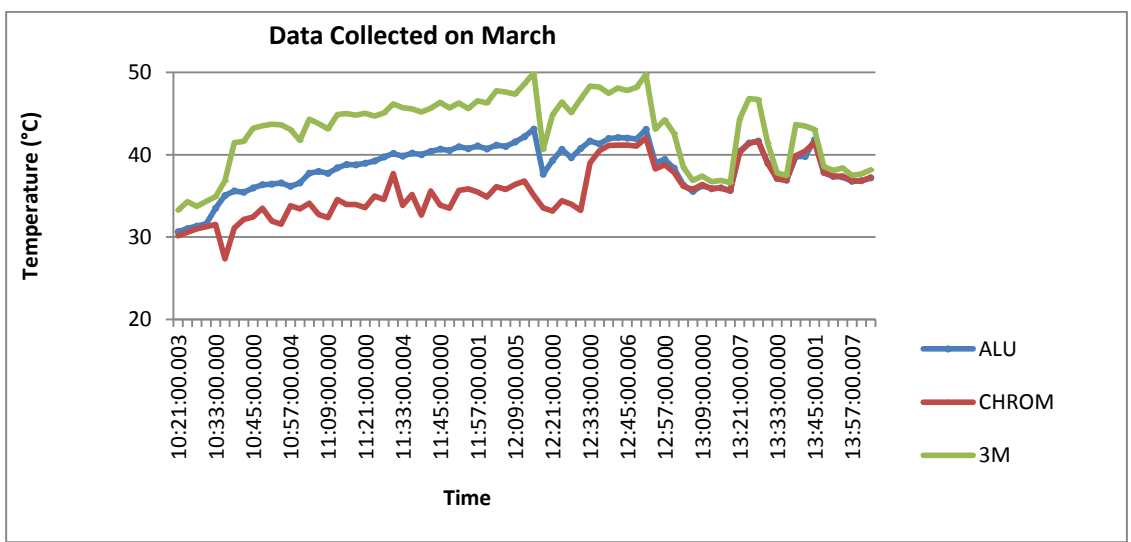

FIGURE 5. Sampling of data collected in March

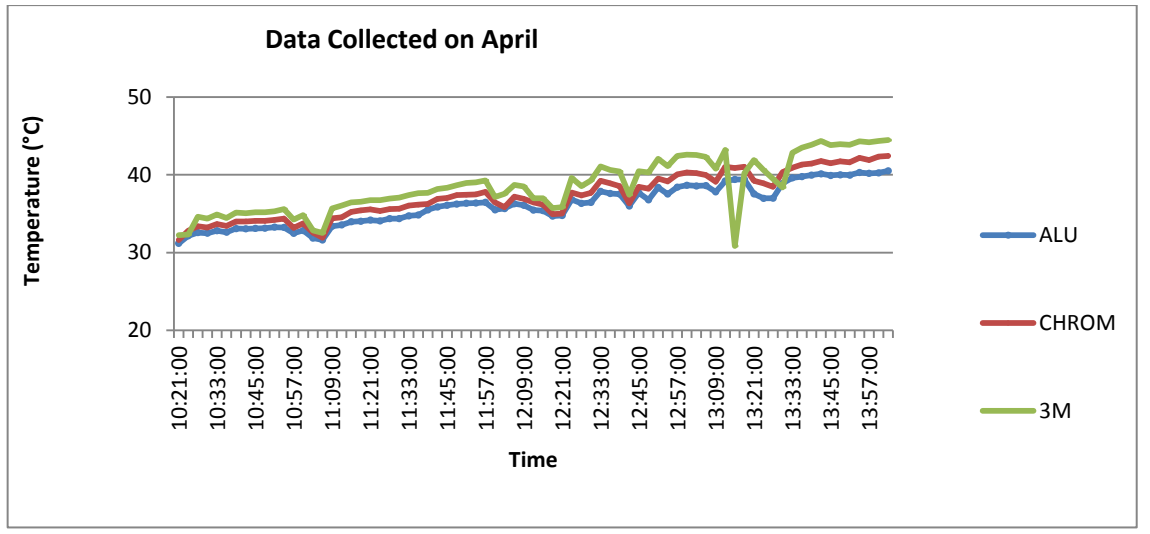

FIGURE 6. Sampling of data collected in April

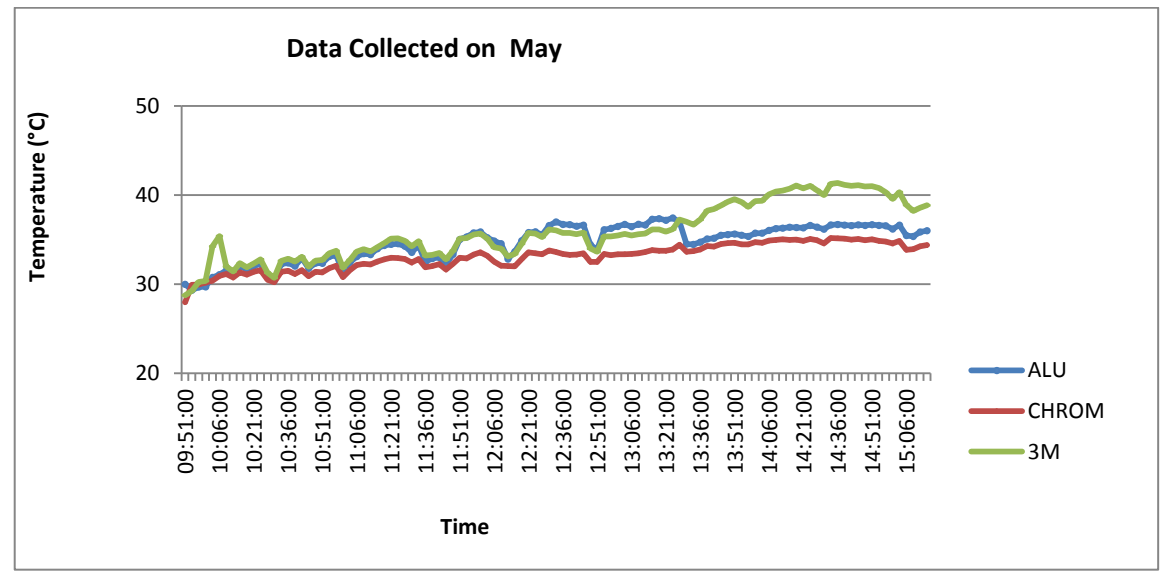

FIGURE 7. Sampling of data collected in May 


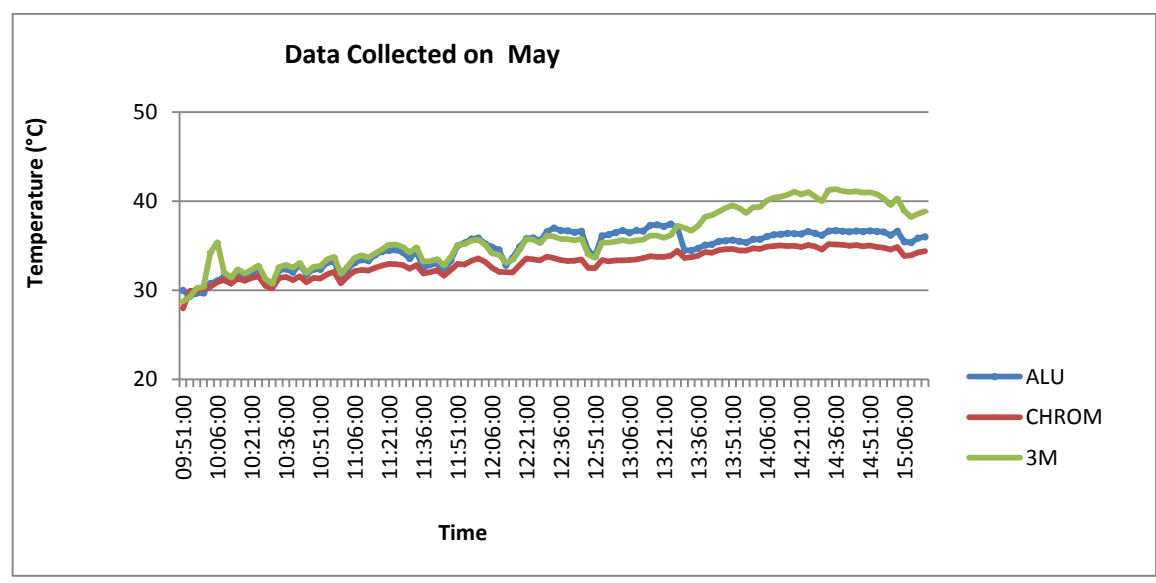

FIGURE 8. Sampling of data collected in June

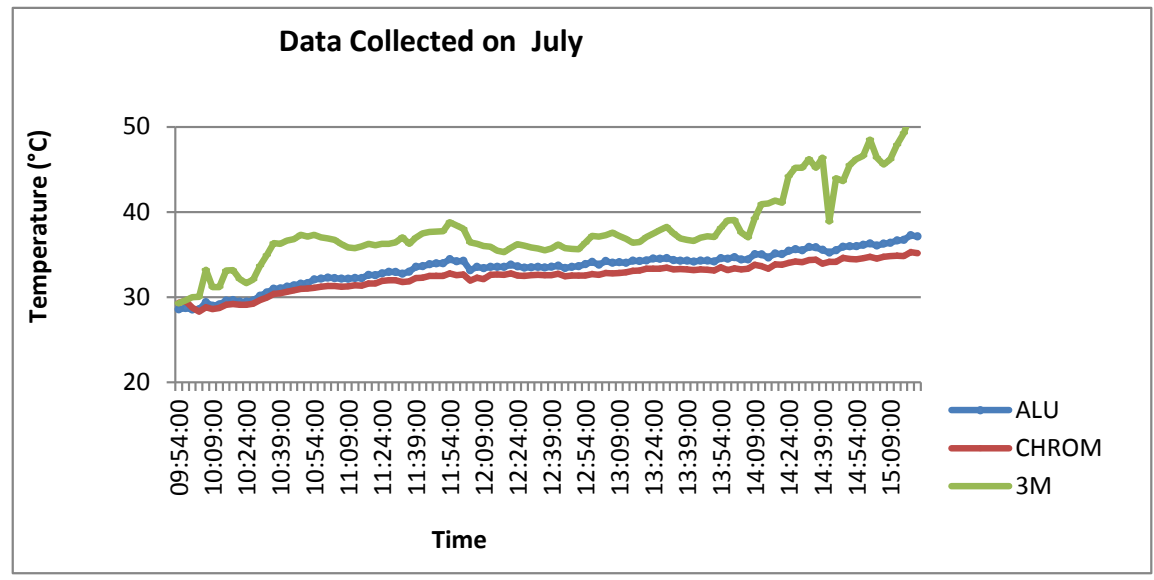

FIGURE 9. Sampling of data collected in July

TABLE 3. Comparison with previous work

\begin{tabular}{lccc}
\hline Materials & Diameter Size $(\mathrm{cm})$ & Average Temperature $\left({ }^{\circ} \mathrm{C}\right)$ & Work done by \\
\hline 3M Aluminum & 32 & 40 & proposed \\
Aluminum & 32 & 37 & proposed \\
Chrome & 32 & 35 & proposed \\
3M Aluminum & 46 & 42 & Rafeeu et. al \\
3M Aluminum & 50 & 45 & Rafeeu et. al \\
Stainless Steel & 45 & 39 & Rafeeu et. al \\
\hline
\end{tabular}

The average temperature is high for $3 \mathrm{M}$ aluminum reflector compared to chrome, aluminum and stainless steel. Comparison with previous work done by (Rafeeu \& Kadir 2012) as shown in Table 3, 3M material is still good reflector even though the dimension of solar dish concentrator is different with our proposed dimension. The average temperature of the reflector material is the highest recorded by $3 \mathrm{M}$ aluminum.

\section{CONCLUSION}

A $3 \mathrm{M}$ aluminum foil is a good reflector material than aluminum and chrome for this solar concentrator dish. This material is light and easy to use. Solar irradiation for any specific location can be measured using pyranometer. This method incurs lower cost and gives accurate results. This data can be used for other solar research applications.

\section{ACKNOWLEDGEMENTS}

The authors would like to thank Universiti Putra Malaysia for providing the research grant for this work.

\section{REFERENCES}

Aghil, S. Mir, H. H., Sopian, K. Sallehuddin, M. H., \& Salem, H. Z. 2013. New formulation for the estimation monthly average daily solar irradiation for the tropics : a case study for peninsular Malaysia. International Journal of Photoenergy article ID 17467.

Ahmad, S., Kadir, M. Z. A. A. \& Shafie, S. 2011. Current perspective of the renewable energy development in Malaysia. Renewable and Sustainable Energy Reviews, 15(2), 897-904. 
Azahari, A.W., Sopian K., Zaharim A., Al Ghoul M. 2008. A new approach for predicting solar radiation in tropical environment using satellite images Case study of Malaysia", WSEAS Transactions on Environment and Development 4 (4): 373-378.

Bakos, G.C. \& Antoniades, Ch. 2013. Techno-economic appraisal of a dish/stirling solar power plant in Greece based on an innovative solar concentrator formed by elastic film. Renewable Energy (60): 446-453.

Hamza, H., Ossama, M. \& Osama E. 2016. Mechanical design of a low cost parabolic solar dish concentrator Mechanical design of a low cost parabolic solar dish concentrator. Alexandria Engineering Journal (55):1-11.

Kamaruddin, A. 2005. Renewable Energy Conversion and Utilization in ASEAN Countries Energy 30:119-128.

Lidula, N.W.A., Mithulananthan, N. Ongsakul, W. Widjaya, C. \& Henson. R. 2007. ASEAN towards clean and sustainable energy: Potentials, utilization and barriers. Renewable Energy (32):1441-1452.

Ozturk, H.H. 2004. Experimental determination of energy and exergy efficiency of the solar parabolic-cooker. Solar Energy, 77(1):67-71.

Rafeeu, Y. \& Kadir M.Z.A.A. 2012. Thermal performance of parabolic concentrators under Malaysian environment: A case study. Renewable and Sustainable Energy Reviews (16):3826-3835.
Reddy, K. S. \& Sendhill, K. N. 2009. Convection and surface radiation heat losses from modified cavity receiver of solar parabolic dish collector with twostage concentartion. Heat and Mass Transfer, 45(3): 363-373.

Solangi, K. H., Islam, M. R., Saidur, R., Rahim, N. A. \& Fayaz, H. 2011. A review on global solar energy policy. Renewable and Sustainable Energy Reviews 15(4): 2149-2163.

\section{Mohd Ali Mat Nong*}

Nor Mariah Adam

Suraya Abdul Rashid

Juraina Md Yusof

Roslina Abdul Rashid

Materials Processing and Technology Laboratory,

Institute of Advanced Technology

Universiti Putra Malaysia

43400 Serdang Selangor, Malaysia

Phone: +603-89467537

${ }^{*}$ Corresponding author; email: mohd_alee@upm.edu.my

Received Date: $27^{\text {th }}$ April 2016

Accepted Date: September 2016 